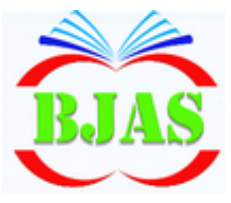

Available online at: http//bjas.bajas.edu.iq

College of Agriculture, University of Basrah

DOi:10.21276/basjas

ISSN $1814-5868$

Basrah J. Agric. Sci., 32(Spec Issue): 247-257, 2019

\section{Basrah}

Journal of Agricultural

Sciences

E-ISSN: 2520-0860

\title{
Study of Antibacterial Activity of some Date Seed Extracts
}

\author{
Nareman A.S. Aljazy*, Aum El-Basher H.J. Al-Mossawi \& Ali K. Al-Rikabi \\ Department of Food Science, College of Agriculture, University of Basrah, Iraq \\ *Corresponding author e-mail: naremanadeem@gmail.com \\ Received 15 March 2019; Accepted 31 August 2019; Available online 10 October 2019
}

\begin{abstract}
Abstract: Eight species of pathogenic and contaminated bacteria were Isolated and identified with the biochemical test and make sure of purity with VITIC2 Technical. The bacteria were Acinetobacter baumannii, Bacillus subtilis, Escherichia coli, Klebsiella pneumoni, Pseudomonas aeruginosa, Proteus mirabilis, Staphylococcus aureus and Streptococcus pyogenes. Investigation effect of aqueous, ethanolic, methanolic of Halawi, Khadrawiand Zahdi date seed extracts on the growth of isolated bacteria, the results showed that ethanolic extract was most effective extract compared to other extracts in influencing on the growth of bacteria using Agar Well Diffusion. The most active extract against $P$. aeruginosa strain was ethanol extract from Zahdi seed with a $22.3+0.32 \mathrm{~mm}$ inhibition zone followed by $20.2+0.22 \mathrm{~mm}$ for Escherichia coli.
\end{abstract}

Key words: Halawi, Khadrawi, Zahdi date seed, Antibacterial activity.

\section{Introduction}

Date seeds that has been considered as a good example of functional food that rich in natural antioxidant involved: Selenium, Phenolic Acids, Carotenoids, when used as crude extracts of active compounds. However; purification and identification many of these materials still pharmacists, chemists and biologists concern, wherever trends to effect of date seed extracts on many of bacterial species besides of antioxidant activity and their a large role of food avidities and extend of shelf life (Fathi,2005).These active compounds in date seed extracts as protein, polyphenols, polysaccharides, lignans, and flavonoids possesses high antibacterial activity as pointed (Habibet al., 2014), that herbal medicine has its roots in every culture around the world; One of the most important medicinal herbs is dates palm (Phoenix dactylifera L.) which is well documented worldwide possesses several highly beneficial properties specially date seed were suggested that must be used as an antibiotic to treat bacterial infections (Saleh, 2016). The aim of this study was to investigate the effects of date seed extracts on contaminated and pathogen bacteria to be used of date seed extracts as antibiotic and additives food.

\section{Materials \& Methods}

\section{Plant material}

Halawi, Khadrawi and Zahdi of Phoenix dactylifera date seed were obtained from local 
market, Basrah. Date and seed have been separated from each other, and then washed and dried. After that, grinding to smooth powder has been done and stored them in a sterilized container for using.

\section{Preparation of date seeds extract}

\section{water extracts}

Followed of method of Ratheesh \& Helen (2007). A weighed $20 \mathrm{~g}$ of date seed powder and their add $500 \mathrm{ml}$ of distilled water, placed in shaking incubator for 24 hours at $28^{\circ} \mathrm{C}$ then centrifuged at $2500 \mathrm{rpm}$ for ten minutes, then filtration by Whitman No.1, concentrated of filtrate byrotary vacuum evaporator tothick liquid, then placed in incubator at $37^{\circ} \mathrm{Cfor} 48$ hours get at dry powder of extract. Put in glass containers and refrigerated at $4^{\circ} \mathrm{C}$.

\section{Ethanolic extract}

Preparation of ethanolic extracts by weighted $100 \mathrm{~g}$ of date seed powder which dissolved by $500 \mathrm{ml}$ ethanol (98\%) and mixed them well and left for 24 hours at laboratory temperature (25$30)^{\circ} \mathrm{C}$. The mixture has filtrated by Whatman No.1 and concentrated by rotary vacuum evaporator at $40^{\circ} \mathrm{C}$ and left at laboratory temperature to get dry powder. Put in glass containers and refrigerated at $4^{\circ} \mathrm{C}$ (Elmastas et al., 2015).

\section{Methanolic extract}

Followed steps in above paragraph (Ethanolic extract)to get at ethanolic date seed extracts.

\section{Antibacterial activity}

\section{Bactrialisolates}

A pathogenic and contaminated food bacterium was isolated in the Microbiology Laboratory at Al-Sadr Teaching Hospital, Basrah.These isolates are Bacillus subtilis, Streptococcus pyogenes, Escherichia coli, Pseudomonas aeruginosa, Klebsiella pneumonia, Proteus mirabilis and Acinetobacter baumannii.
Each one bacterial isolates were initially identified depending on the forms of their developing colonies on the various plant media. This included the height of colonies (curved or flat), their shape, nature of their edges, their transparency, their colours, and their pigmentation, uses of MacConkey agar and Blood agar for recognize positive or negative bacteria and there were used other media for recognize $E$. coli from other negative gram bacteria such as Eosin methylene blue agar and Mannitolsalt agar was selective and differential for organisms such as Staphylococcus species which can live in areas of high salt concentration and Mueller-Hinton agar for antibacterial activity test.Some biochemical diagnostic tests were based on, such as catalysis, oxidase testing, coagulation enzyme testing, and sugar fermentation testing (Holt et al., 1994).Then the VITIK technique was used to diagnose the Gram-negative and Gram-positive bacteria after been confirmed by initial biochemical tests, consisting of a cassette holder and 64-hole Reagent cards represents the base material or medium for testing, plastic tubes as well as Densichek device and the input and output units, and it is considered as one of the best devices to identify the types of bacteria in a short period and very accurately (Ligozziet al., 2002).

\section{Media}

Sterilize all the media in the autoclave device at $121{ }^{\circ} \mathrm{C}$ and press $15 \mathrm{lb} . \mathrm{kg}^{-2}$ for 15 minutes. All media used in insulation were prepared according to the manufacturer's instructions (Table 1).

\section{Biochemical test}

1- Catalase Test: Is a test for demonstrating the presence of catalase enzyme by decomposition of hydrogen peroxide to oxygen and water, the reagent used for qualitative catalase testing is $3 \%$ hydrogen peroxide, though up to $6 \%$ is acceptable, the test can be done by mixing a 
Aljazy et al. / Basrah J. Agric. Sci., 32 (Special Issue): 247-257, 2019

Table (1): Culture media used in study.

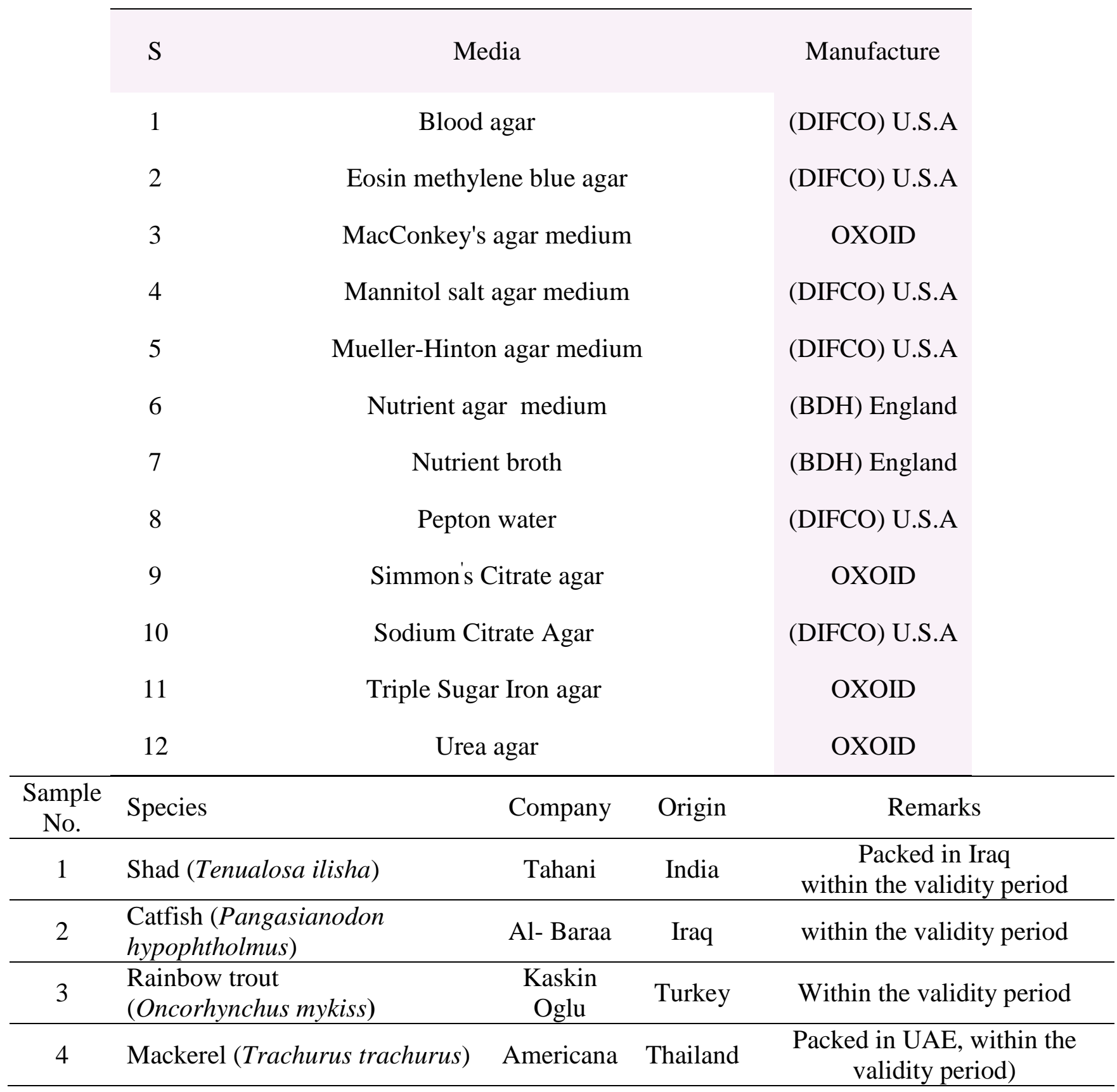

colony with a few drops of $\mathrm{H}_{2} \mathrm{O}_{2}$ in a slide and looking for the formation of bubbles within 10 sec.

2- Oxidase Test: The test identifies the presence of cytochrome $\mathrm{c}$ oxidase or indophenols oxidase, the test is based on the principle of redox (Reduction-oxidation), the oxidase test often uses a reagent as an electron donor, when the reagent is oxidised it changes from colourless to a dark blue or purple compound, indophenol blue.
3-Indole Production Test: Indole is an aromatic heterocyclic organic compound with asixmembered benzene ring fused to a five-membered nitrogen-containing pyrrole ring, which is derived from tryptophan using the enzyme tryptophanase, Indole can be detected easily with Kovacs reagent.

4- Methyl-Red Test: The MR test looks for the ability of bacteria to produce large amounts of acid resulting in significant decrease in the $\mathrm{pH}$ of the medium below $\mathrm{pH} 4.4$, this acidic nature 
is indicated by methyl red indicator which is yellow above $\mathrm{pH} 5.1$ and red at $\mathrm{pH}$ 4.4. The test is done on glucose phosphate peptone water.

5- Voges -Proskauer test: VP test is actually extension of MR test and looks for the ability to produce butylenes products. Acetoin is an intermediate in the reaction which is looked for using $40 \% \mathrm{KOH}$ and alpha-naphthol. If Acetoin is present, it is oxidised in the presence of air and $\mathrm{KOH}$ to diacetyl which reacts with guanidine components of peptone, in the presence of alpha-naphthol to produce a red colour.

6- Citrate Utilization test: The test looks for the ability of a bacteria to utilise citrate as a sole source of carbon. The organism is inoculated into simmonscitrate agar, simmons citrate agar contains sodium citrate as the sole source of Carbone, ammonium dihydrogen phosphate as the sole source of nitrogen, and the $\mathrm{pH}$ indicator bromothymole blue. The bacteria convert the ammonium dihydrogen phosphate to ammonia, at $\mathrm{pH} 7.5$ or above bromothymol blue turns royal blue which is otherwise green.

7- Sugar Ferment Test: The test medium is Triple Sugar Iron agar (TSI), the test medium contains 3 sugars-Glucose $(0.1 \%)$, lactose and sucrose (1\% each). Phenol red serves as the indicator, the medium contains a butt and a slant, Ferrous sulphate serves as an indicator for $\mathrm{H}_{2} \mathrm{~S}$ production. The medium is inoculated with a stab method on the butt and stroke method on slant. The organisms ferments glucose but does not ferment lactose or sucrose, the slant becomes red and butt remains yellow. It is reported as K/A(Alkaline slant/Acid butt), the organisms in addition to glucose ferments lactose and sucrose. The slant and butt remain yellow, it is reported A/A(Acid slant /Acid butt), if the organisms in non-fermenter, it is reported K/NC (Alkaline slant/ No change), in addition to the above gas and $\mathrm{H}_{2} \mathrm{~S}$ is reported.
8- Urease test :Urease is an enzyme belong to the superfamily of amidohydrolases and phosphotriesterases. It catalyses the hydrolysis of urea into ammonia and carbon dioxide. The formation of ammonia causes alkalinisation of the medium and the $\mathrm{pH}$ change is indicated by a change to pink at pH 8.1 (Betty et al., 2007).

\section{3-Test assay for antibacterial activity of date seed extracts}

The antibacterial activity was determined by using agar well diffusion method. A volume of 0.1 $\mathrm{ml}$ of eight different strains was inoculated to the test tube, and incubated overnight. Muller Hinton agar was prepared in a conical flask and sterilized in autoclave. The sterile medium was poured into petri plates, Bacterial cultures were uniformly spread over the media using cotton swab, then wells of about $6 \mathrm{~mm}$ in diameter were punched in Muller Hinton agar by using cork borer. Then, the wells was loaded with $50 \mu \mathrm{l}$ of seed extract at concentration $(5 \mathrm{mg} / \mathrm{ml})$. The inoculated plates were incubated at $37^{\circ} \mathrm{C}$ for $24 \mathrm{hrs}$. The diameters of inhibition zones were measured for each plate(Perez et al., 1990).

\section{Statically analytics}

The data analyzed by ANOVA test and Analysis of Variance at probability level $\mathrm{P}<0.05$ within SPSS Statistical Package of Social Sciences and used RLSD (Al-Rawi \& Khalaf-Allah, 2000).

\section{Result \& Discussion}

\section{Biochemical test}

\section{1-Acinetobacter baumannii}

Negative for Gram stain, Oxidase, Indole test, Methyl Red, Voges-Proskauer Test, Urease and $\mathrm{H}_{2} \mathrm{~S}$ gas, Indole, and has non-spores, while is positive for catalase, Glucose fermented, nonLactose or sucrose fermented. It was an opportunistic pathogen in humans, affecting people with compromised immune systems becoming increasingly important as a hospital- 
derived (nosocomial) infection (Holt et al., 1994).

\section{2- Bacillus subtilis}

It is positive for gram stain, catalase, citrate, oxidise, Voges Proskauer Test, It has the ability to ferment the lactose, sucrose, andglucose, while it is negative for indole, urease, methyl red and $\mathrm{H}_{2} \mathrm{~S}$ gas.

\section{3- Escherichia coli}

It is negative for gram stain, citrate test, Voges Proskauer Test, oxidase, urease, $\mathrm{H}_{2} \mathrm{~S}$ test, while it is positive for Indole test, catalase, methyl red test and It has the ability to ferment the lactose, sucrose, and glucose.

\section{4-Klebsiella pneumonia}

It is positive for catalase, citrate, Voges Proskauer Test, urease test, while is negative for gram stain, oxidase, indole, methyl red, $\mathrm{H}_{2} \mathrm{~S}$ gas. Also it is fermented the glucose, lactose and sucrose.

\section{5- Proteus mirabilis}

Proteus mirabilis is negative for gram stain, glucose ferment, oxidase, Voges Proskauer Test, Indole test, non-lactose, sucrose ferment, while it is positive for citrate, catalase, urease, Methyl Red and $\mathrm{H}_{2} \mathrm{~S}$ test.

\section{6-Pseudomonas aeruginosa}

It is positive for citrate, catalase, oxidase test, while negative for $\mathrm{H}_{2} \mathrm{~S}$ gas, urease, indole, voges-proscauer, methyl red test, and non lactose, glucose and sucrose ferment.

\section{7-Staphylococcus aureus}

It is positive for gram stain, catalase, citrate, urease, Voges-Proskauer, Methyl Red Test and lactose- sucrose- glucose ferment, while negative for Indole, oxidase and $\mathrm{H}_{2} \mathrm{~S}$ gas test.
These bacteria is Gram-positive, negative for gatalase, oxidase, urease, Voges-Proskauer, Indole, $\mathrm{H}_{2} \mathrm{~S}$ gas test while is positive for Methyl Red and Citrate test also fermented for lactose, sucrose, and glucose.

\section{2- Analysis of VITIK2 Technique}

The VITIK2 system was used for rapid identification of isolates and result calculated. Also, comported with results a store in instrument which was involved with many of strains grow in different conditions and isolated from variety places. System showed results of tester as,,$+-(+)$ and (-). The results in parentheses indicate weak testing, and defined of identification level for organisms by test mapping and compared with mental adjective of system and was given probability percentage and accuracy level reach to $96-99 \%$.

\section{3-Antibacterial of Halawi date seed extracts}

The results obtained have showed that most of seed extract possesses a potential antibacterial activity against the tested bacteria; However, ethanolic and methanolic of Halawi date seed extracts had a significant $(\mathrm{P}<0.05)$ antibacterial agents than the aqueous extracts (Table 3). These extracts (ethanolic and methanolic) inhibited all organism, the methanolic extracts was the maximum rate of effectiveness inhibitory towards $P$. mirabilis diameter $20 \mathrm{~mm}$, then $K$. pneumonia diameter $15 \mathrm{~mm}$, and other organism which was $11 \mathrm{~mm}$ and $12 \mathrm{~mm}$, while ethanolic extracts was the maximum rate of effectiveness inhibitory against $P$. aeruginosa diameter $17 \mathrm{~mm}$, and the rang of inhibition zone of other strains between $10-12 \mathrm{~mm}$. However, the minimum effect was for aqueous extract which showed low zone of inhibition against $P$. aeruginosa, $K$. pneumoniae, A.

\section{8-Streptococcus pyogenes}

Table(2): Biochemical test of isolated bacteria. 


\begin{tabular}{|c|c|c|c|c|c|c|c|c|}
\hline Bacteria Types of & 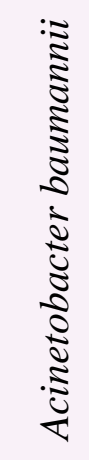 & 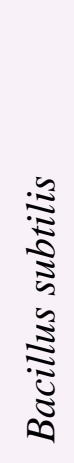 & 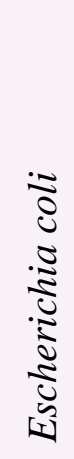 & 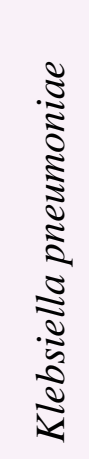 & 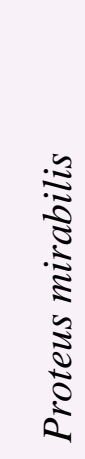 & 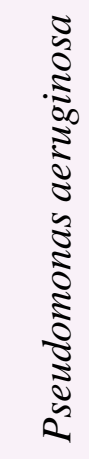 & 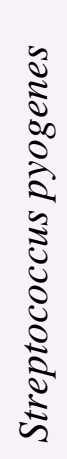 & 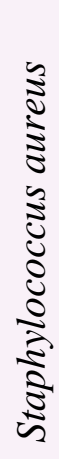 \\
\hline Gram stain & - & + & - & - & - & - & + & + \\
\hline Catalase production test & + & + & + & + & + & + & - & + \\
\hline Oxidase production test & - & + & - & - & - & + & - & - \\
\hline Detection of Indole production & - & - & + & - & - & - & - & - \\
\hline Methyl red test & - & - & + & - & + & - & + & + \\
\hline Voges - proskauer test & - & + & - & + & - & - & - & + \\
\hline Citrate test & + & + & - & + & + & + & + & + \\
\hline Urine test & - & - & - & + & + & - & - & + \\
\hline Glucose fermention & + & + & + & + & + & - & + & + \\
\hline Sucrose fermention & - & + & + & + & - & - & + & + \\
\hline Lactosefermention & - & + & + & + & - & - & + & + \\
\hline $\mathrm{H} 2 \mathrm{~S}$ & - & - & - & - & + & - & - & - \\
\hline
\end{tabular}

baumannii and $P$. mirabilis, while inhibition zone of other organisms with $7 \mathrm{~mm}, 7 \mathrm{~mm}$, $6 \mathrm{~mm}, 8 \mathrm{~mm}$ against to E. coli, S. aureus, B. subtilis and $S$. pyogenes respectively. The antibacterial activity of these extracts due toas alkaloids, sterols, carbohydrates, flavonoids vitamins, tannins and phenolic acids (Eong, 2006). The results agreed with Perveen et al. (2012) which found the antibacterial activity of methanolic extract was the maximum rate of effectiveness inhibitory towards pathogenic bacteria than aqueous and acetone extracts. Also, agreed with Saleh (2016) which notice the ethanolic and chloroform extracts of Khastawi date seed was the best than aqueous extract of antibacterial activity, This due to the ability of organic solvents to extraction high level of phenolic compounds (Cox et al., 2001). The inhibition of bacterial growth by these extracts could be due to the presence of some active compounds which may act alone or in combination to inhibit bacterial growth (Mohammedi \& Atik, 2011). Also table (2) noticed Halawi date seed extracts was effective in influencing the growth of pathogenic or contaminated bacteria such as B. subtilis and $S$. aureus. Different results and selective inhibition of extracts against bacteria may due 
to extraction condition and type of solvents uses (Habib et al., 2014) in addition ethanol was consider common solvent with low poisoning to extract active compound and uses of introduction of many materials such as makeup, flavour and colour in food industry.

4-Antibacterial of Khadrawi date seed extracts
The table (4) showed results in the inhibition effect of aqueous, ethanolic, methanolicextracts of Khadrawi date seed against pathogenic bacteria, also showed the inhibition effect be varied by bacteria species, ethanolic and methanolic of Khadrawi date seed extracts had a significant value $(\mathrm{P}<0.05)$ antibacterial agents than the aqueous extracts, these two extracts showed inhibition effect against all bacteria, as was the maximum rate of effectiveness

Table (3): Inhibitory zone of Halawi date seed against pathogenic bacteria.

\begin{tabular}{lcccc}
\hline \multirow{2}{*}{ Bacterial Species } & \multicolumn{3}{c}{ Inhibition zone diameter (mm) } & \\
\cline { 2 - 4 } & $\begin{array}{c}\text { Ethanolic } \\
\text { extract }\end{array}$ & $\begin{array}{c}\text { Methanolic } \\
\text { extract }\end{array}$ & $\begin{array}{c}\text { Aqueous } \\
\text { extract }\end{array}$ & \\
\hline Acintobacter baumanii & 12 & 10 & $\begin{array}{c}\text { weak } \\
\text { Inhibition }\end{array}$ & N.S \\
\hline Bacillus subtilis & 12 & 11 & 6 & 4.8 \\
\hline Escheichia coli & 13 & 12 & 7 & 4.5 \\
\hline Klebsiella pneumoniae & 9 & 15 & $\begin{array}{c}\text { weak } \\
\text { Inhibition }\end{array}$ & 5.2 \\
\hline Proteus mirabilis & 10 & 20 & $\begin{array}{c}\text { weak } \\
\text { Inhibition }\end{array}$ & 6.4 \\
\hline Pseudomonas aeruginsa & 17 & 11 & $\begin{array}{c}\text { weak } \\
\text { Inhibition }\end{array}$ & 3.7 \\
\hline Staphylococcus aureus & 12 & 12 & 7 & 3.2 \\
\hline Streptococcus pyogenes & 11 & 11 & 8 & 2.4 \\
\hline Inhibition Average & 12 & 11.4 & 7 & 4.6 \\
\hline & & & & \\
\hline
\end{tabular}

inhibitory towards $A$. baumannii by ethanolic extract diameter $14 \mathrm{~mm}$. Then $K$. pneumoniae, S. pyogenes diameter $12 \mathrm{~mm}$, and other bacteria $11 \mathrm{~mm}, 10 \mathrm{~mm}$, while methanolic bacteria was the maximum rate of effectiveness inhibitory towards $P$. aeruginosa

diameter of inhibition zone was $14 \mathrm{~mm}$. The inhibition zone diameter of other bacteria ranged between 10 to $11 \mathrm{~mm}$, and the minimum 
effect was for aqueous extract which showed low level inhibition for each $K$. pneumoniae, $A$. baumannii, $P$. aeruginosa, while diameter of other species $6 \mathrm{~mm}, 7 \mathrm{~mm}, 8 \mathrm{~mm}, 8 \mathrm{~mm}, 6 \mathrm{~mm}$ for E. coli, S. aureus, B. subtilis, S. pyogenes and $P$. mirabilis respectively. The antibacterial activity of these extracts due to presence phenolic compounds which aromatic compounds contained hydroxyl group and inhibition ability of these compounds increased by rise of these groups (Al-Moussaoui, 2006).
The results agreed with Mossa et al. (1986) were found alcoholic extract of date seed showed antibacterial activity on $K$. pneumoniae growth, also agreed with Saddiq \& Bawazir (2010) were noticed alcoholic extract of date seed possesses antibacterial activity against $S$. aureus, Proteus and Bacillus. In addition, was more effective in inhibiting growth of most tested bacteria as compared with antibiotics and

Table (4): Inhibitory zone of Khadrawidate seed against pathogenic bacteria.

\begin{tabular}{lcccc}
\hline \multirow{2}{*}{ Bacterial Species } & \multicolumn{3}{c}{ Inhibition zone diameter (mm) } & L.S.D \\
\cline { 2 - 4 } & $\begin{array}{l}\text { Ethanolic } \\
\text { extract }\end{array}$ & $\begin{array}{c}\text { Methanolic } \\
\text { extract }\end{array}$ & $\begin{array}{c}\text { Aqueous } \\
\text { extract }\end{array}$ & \\
\hline Acintobacter baumanii & 14 & 11 & $\begin{array}{c}\text { weak } \\
\text { Inhibition }\end{array}$ & 2.8 \\
\hline Bacillus subtilis & 10 & 10 & 8 & N.S \\
\hline Escheichia coli & 11 & 9 & 6 & 2.5 \\
\hline Klebsiella pneumoniae & 12 & 11 & $\begin{array}{c}\text { weak } \\
\text { Inhibition }\end{array}$ & \\
\hline Proteus mirabilis & 10 & 8 & 6 & 2.6 \\
\hline Pseudomonas aeruginsa & 10 & 14 & $\begin{array}{c}\text { weak } \\
\text { Inhibition }\end{array}$ & 3.5 \\
\hline Staphylococcus aureus & 11 & 11 & 7 & 3.2 \\
\hline Streptococcus pyogenes & 12 & 11 & 8 & 3.4 \\
\hline Inhibition Average & 10 & 10.6 & 7 & 2.7 \\
\hline & & & & \\
\hline
\end{tabular}

this may refer to difference in resistance of bacteria to anti-tested material due to change in membrane permeability of cells, thereby hindering the entry of enzymes or excretions by the change in the chemical composition of the constituent chemical or by changing the natural of some of their components (Aba Al- Khail et al., 2003).

\section{5-Antibacterial of Zahdi Date Seed Extracts}

Results showed in table (5) the inhibition effect of aqueous, ethanolic, methanolic extracts of 
Aljazy et al. / Basrah J. Agric. Sci., 32 (Special Issue): 247-257, 2019

Zahdi date seed against pathogenic bacteria also showed the inhibition effect be varied by bacteria species, ethanolic and methanolic of Zahdi date seed extracts had a

Table (5): Inhibitory zone of Zahdidate seed against pathogenic bacteria by $\mathbf{m m}$.

\begin{tabular}{lcccc}
\hline \multirow{2}{*}{ Bacterial Species } & \multicolumn{2}{c}{ Inhibition zone diameter (mm) } & L.S.D \\
\cline { 2 - 4 } & $\begin{array}{l}\text { Ethanolic } \\
\text { extract }\end{array}$ & $\begin{array}{c}\text { Methanolic } \\
\text { extract }\end{array}$ & $\begin{array}{c}\text { Aqueous } \\
\text { extract }\end{array}$ & \\
\hline Acintobacter baumanii & 16 & 10 & $\begin{array}{c}\text { weak } \\
\text { Inhibition }\end{array}$ & 4.2 \\
\hline Bacillus subtilis & 12 & 14 & 8 & 2.1 \\
\hline Escheichia coli & 20 & 8 & 7 & 5.9 \\
\hline Klebsiella pneumoniae & 13 & 10 & $\begin{array}{c}\text { weak } \\
\text { Inhibition }\end{array}$ & N.S \\
\hline Proteus mirabilis & 22 & 9 & $\begin{array}{c}\text { weak } \\
\text { Inhibition }\end{array}$ & 4.6 \\
\hline Pseudomonas aeruginsa & 15 & 16 & 8 & 3.4 \\
\hline Staphylococcus aureus & 12 & 10 & 8 & 1.9 \\
\hline Streptococcus pyogenes & 12 & 11 & 8 & 2.3 \\
\hline Inhibition Average & 15.3 & 10 & 7.8 & 3.5 \\
\hline
\end{tabular}

significant $(\mathrm{P}<0.05)$ antibacterial agents than the aqueous extracts, as was the maximum rate of effectiveness inhibitor against $P$. aeruginosa and $E$. coli by ethanolic extract diameter $22 \mathrm{~mm}$ and $20 \mathrm{~mm}$ respectively. These results agreed with Ado et al. (2017) about study inhibition effect of active compounds in date seed extract against Escherichia coli. Also the extracts showed presence bio active compounds such as Alkaloids, Glycoside and Saponins which responsible of extracts ability of inhibition isolated bacteria E.coli $20 \mathrm{~mm}$ and concentration $1 \mathrm{mg} \cdot \mathrm{ml}^{-1}$, while diameter of other bacteria reach 12, 13, 15, $16 \mathrm{~mm}$ for S.aureus, K. pneumoniae, $P$. mirabilis and A. baumannii respectively, while methanolic extract which was at most activity with $16 \mathrm{~mm}$ diameter against $P$. mirabilis. Inhibition zone diameter for other bacteria arranged between 8 to $14 \mathrm{~mm}$ ,the minimum inhibition activity was aqueous extract showed low inhibition level on $P$. aeruginosa, K. pneumonia and A. baumannii. Inhibition zone diameter for other

bacteria $7 \mathrm{~mm}$ for E. coli, $8 \mathrm{~mm}$ for $S$. aureus, $B$. subtilis, S. pyogenes and P. mirabilis, these results agreed with Al-Moussaoi \& AbdAlmotalib (2011) of study about phenolics activity which extracts from different parts of date palm against bacteria caused Blepharitis, showed phenolic compounds extracts high antibacterial activity against isolated bacteria, phenolic compound work on inhibition growth of cells by effect on cell well activity and deposition of cells protoplasm accordingly their death (Gende et al., 2008; Trajeno et al., 2010).

\section{Conclusions}


Phoenix dactylifera seeds extract has antibacterial effect against Isolated bacteria due to abundance of phytochemical in the seeds.

\section{Acknowledgements}

The authors would like to give thanks to Department of Food Science, College of Agriculture, University of Basrah for using lab.

\section{References}

Aba Al-Khail, A.A.; Ibrahim, J.H. \&Waveform, K.M. (2003). A practical book in Microbiology. First Printing, Publisher. Majority of the publishing and distribution Riyadh. Saudi Arabia: 270pp.

Ado, A.; Chonoko, U.G. \& Abdul-Azeez, U.M. (2017). Antibacterial activity of Phoenix dactylifera L. (Date palm)seeds extract against Escherichia coli. UMYU J. Microbiol. Res., 2:1.

Al-Moussaoui, M.A. (2006). Antibacterial activity of Iraqi plants. M. Sc. Thesis. Coll. Educ., Univ. Basrah: 85pp.

Al-Moussaoui, M. \& Abd -Almotalib, Y. (2011). Detection of Phenolic compound activity extracted from date palm against to blepharitis bacteria. Basrah J. Date Palm Res., 1(2): 124-137.

Al-Rawi, K.M .\& Khalaf-Allah, A.M. (2000). Design and Analysis of Experiments Agricultural. Design and Analysis of Agricultural Experiments. Foundation of Dar Al-Ktob. Univ. Mosul, Min. High. Educ. Sci. Res., Iraq: 488pp. (In Arabic).

Betty, A.; Daniel, F. \&Alice, S. (2007). Diagnostic Microbiology. $12^{\text {th }}$ ed. Mosby. 24: 1056pp.

Cox, S.D.; Mann, C.M. \&Markham, J.L. (2001). Interactions between components of the essential oil Melaleuca alternifolia .J. Appl. Microial., 91: 492-497.
Elmastas, M.; Cinkilic, S. \& Aboul-Enein, H.Y. (2015). Antioxidant capacity and determination of total phenolic compounds in Daisy (Matricaria chamomilla, Fam. Asteraceae. World J. Anal. Chem., 3: 9-14.

Eong, Y.J.; Hong, F.A.; Tomas-Barberan, F.A.; Adel, A.; Kader, S. \& Alyson, E. (2006). The flavonoid glycosides and procyanidin composition of Deglet Noor dates (Phoenix dactylifera). J. Agric. Food Chem., 54: 24052411.

Fathi, H.A. (2005). Date Palm. Life Trees. Arabian Publ. distribution house. $1^{\text {st }}$ ed. Cairo: 588pp.

Gende, L.B.; FlorisFritz, R. \& Ecuaras, M.J. (2008). Antimicrobial activity of cinnamon (Cinnamomum zeylanicum) essential oil and its main components against Peanibacillus larvae from Argentine. B. Insectol., 61(1): 14.

Habib, H.M.; Platat, C.; Meudec, E.; Cheynier, V. \& Ibrahim, W.H. (2014). Polyphenolic compounds in date fruit seed (Phoenix dactylifera): Characterisation and quantification by using UPLC-DAD-ESI-MS. J. Sci. Food Agric., 94(6): 1084-1089 .

Holt, J.G.; Krieg, N.R; Sneathm, P.H.A; Staly, J.T. \& Williams, S.T. (1994). Bergey's Manual of Determinative Bacteriology. ${ }^{\text {th }}$ ed. Baltimore, M.D.: Williams \& Wilkins: 787pp.

Ligozzi, M.; Bernini, C.; Bonora, M.G.; Fatima, M.D.; Zuliani, J. \& Fontana, R. (2002). Evaluation of the VITEK2 System for identification and antimicrobial susceptibility testing of medically relevant gram-positive cocci. J. Clin. Microbiol., 40(5): 1681-1686 .

Mohammedi, Z. \& Atik, F. (2011).Impact of solvent extraction type on total polyphenolis content and biological activity from Tamarixaphylia (L.) karst. Int. J. Pharmacol. Biol. Sci., 2(1): 609-615. 
Mossa, J.S.; Hifnawy, M.S. \& Mekkawi, A.G. (1986). Phytochemical and biological investigations on date palm seeds (Phoenix dactylifera L.) produced in Saudi Arabia. Arab. Gulf J. Sci. Res., 4: 495-507.

Perez, Z.C.; Pauli, M. \& Bazergue, P. (1990). Antibiotic assay by the agar-well diffusion method. J. Acta Biologic. Acta Biol. Med. Exp., 15: 113-115.

Perveen, K.; Bokhari, N.A. \& Soliman, D.A.W. (2012). Antibacterial activity of (Phoenix dactylifera L.) leaf and pit extracts against selected Gram negative and Gram positive pathogenic bacteria .J . Med. Plant Res., 6(2): 296-300.

Ratheesh, M. \&Helen, A. (2007). Antiinflammatory of Ruta graveolens L. on carrageenan induced paw edema in wistar male rats. Afr. J. Biotech., 6(10): 1209-1211.

Saddiq, A.A. \& Bawazir, A.E. (2010). Antimicrobial activity of date palm (Phoenix dactylifera) pits extracts and its role in reducing the side effect of methyl prednisolone on some neurotransmitter content in the brain, hormone testosterone in adulthood. $4^{\text {th }}$ Int. Date Palm Conf. Acta Hort., 882: 665-690.

Saleh, F.R. (2016). Antibacterial activity of seeds of Iraqi dates. J. Biol. Innov., 5(2): 313-318.

Trajeno, -V.N.; Linda, E.O.; Travassos , A.E. \& Souza, E.L. (2010). Inhibitory effect of the essential oil from Cinnamomum zeylancium Blume leaves on some food related bacteria. Cienc. Tecnol. Aliment. Campians., 30(3): 771-772. 